\title{
Case Marker Assignment Abilities as a Function of the Noun Types of Thematic Roles in Aphasia
}

\author{
Jimin Park, Jee Eun Sung \\ Department of Communication Disorders, Ewha Womans University, Seoul, Korea
}

Correspondence: Jee Eun Sung, PhD Department of Communication Disorders, Ewha Womans University, 52 Ewhayeodae-gil, Seodamun-gu, Seoul 03760, Korea

Tel: $+82-2-3277-2208$

Fax: +82-2-3277-2122

E-mail: jeesung@ewha.ac.kr

Received: July 2, 2020

Revised: July 30, 2020

Accepted: August 8, 2020

This work was supported by the Ministry of Education of the Republic of Korea and the National Research Foundation of Korea (NRF-2019R1A2C1089280)

\begin{abstract}
Objectives: The purpose of this study was to investigate the ability in case marker (CM) assignment according to noun types of thematic roles in people with aphasia (PWA). CM errors were analyzed and the correlation between noun types and the severity of aphasia was examined. Methods: Eighteen PWA and twenty normal adults participated in this study. The CM assignment task was conducted by presenting participants with two different noun types of thematic roles and one verb, and the participants were asked to produce the appropriate $\mathrm{CM}$ for each noun. Responses were calculated by accuracy (\%) and the error types were analyzed. Results: First, PWA performed significantly lower than the normal adults, especially in instrument nouns of thematic roles when compared with location and theme. Second, PWA showed four times more substitution errors than omission errors, which is a representative characteristic in inflectional languages. Instrumental and locative $\mathrm{CMs}$ were mostly substituted with accusative $\mathrm{CMs}$, and accusative $\mathrm{CMs}$ were mostly substituted with locative $\mathrm{CMs}$. The most predictable variable for aphasia severity were the location nouns of thematic role, at approximately $48.2 \%$. Conclusion: PWA showed significantly lower accuracy compared to normal adults, indicating that PWA have difficulties in comprehending syntactic and semantic relationships between arguments. Since lexical retrieval is highly related to the frequency effect and PWA have highly preserved spatial cognition, syntactic processing abilities were mostly affected in comprehending location thematic roles. Thus, the location was highly correlated to aphasia severity. Moreover, CM assignment may be clinically useful because it is simple to conduct and can be used for deep testing.
\end{abstract}

Keywords: Thematic role, Case marker, Verb, Aphasia
문장을 적절하게 이해하고 산출하기 위해서는 문장을 구성하는 핵심 품사인 동사를 중심으로 문장 성분, 즉 논항(argument) 간의 관계를 파악해야 한다(Kwon, 2009; Wambaugh, Doyle, Martinez, \& Kalinyak-Fliszar, 2002). 논항 간의 관계는 통사론적 측면 또는 의미론적 측면으로 설명할 수 있는데 어떤 측면으로 설명하는지에 따라 논항을 다르게 명명한다. 통사론적 측면에서는 각 논항을 주 어(subject), 목적어(object), 서술어(verb)와 같이 명명하는 반면, 의 미론적 측면에서는 행위자(agent), 피동자(patient), 대상(theme), 도구(instrument), 장소(location) 등으로 명명한다(Dik, 1997; Fillmore, 1968; Jackendoff, 1972). 이처럼 동사를 중심으로 의미론적 개념이 부여된 논항을 의미역(thematic role)이라 부른다(Carlson
\& Tanenhaus, 1988; McRae, Hare, \& Tanenhaus, 2005; Yi, 2019). 예를 들어, '가위로 종이를 자르다.'라는 문장에서 '무엇으로 자르는 가?'와 ‘무엇을 자르는가?’로 의미역을 알 수 있다. '무엇으로'에 해당 하는 동사의 의미역은 도구(instrument)로 위 문장에서 '가위로'에 해당하고, '무엇을'에 해당하는 동사의 의미역은 대상(theme)으로 위 문장에서 '종이'에 해당한다. 이처럼 문장 내에서 의미역 간 관계 를 통합적으로 해석하는 과정을 의미역 처리(thematic processing) 라 부르며, 이 과정은 문장 내 의미역 순서에 따라 순차적인 과정으 로 나타나는 것이 아니라 점진적 혹은 증가적(incremental)으로 나 타나고, 모든 의미역 정보가 활성화된 상태에서 이루어지는 복잡 한 과정으로 이루어진다(Carlson \& Tanenhaus, 1988; Rayner, 
Carlson, \& Frazier, 1983).

Fillmore (1968)는 의미역 처리가 의미역 위계(thematic hierarchy)를 토대로 이루어진다고 하며, 의미역 위계는 주어 선택(selection)을 결정하는데 중요한 역할을 한다고 하였다. 의미역의 위계는 문장 구조와 문장 내 성분들 간의 의미 관계를 어떻게 파악할 것인 지에 따라 다양한 도출방법을 가진다. 크게 세 가지로 분류할 수 있 는데, 첫째, 통사 구조(syntactic structure)에 의한 도출, 둘째, 의미 역 계층(thematic hierarchy)에 의한 도출, 셋째, 주제화 계층(topicality hierarchy)에 의한 도출이다(Chomsky, 1986; Dik, 1997; Fillmore, 1968; Givón, 1983; Han, 2001; Jackendoff, 1972). 그 중 의미 역 계층에 의한 도출은 문장 내 명사구 간의 문법적인 관계가, 즉 논항 구조(argument structure)가 의미역과 관련이 있을 수밖에 없 다는 생각에서 출발한다(Han, 2001). Dik (1997)은 의미 기능 계층 (Semantic Function Hierarchy, SFH)을 토대로 통사 구조 상 주어 나 목적어에 해당하는 의미역이 '행위자>도달점 $=$ 대상 $>$ 피동자 $>$ 수혜자>도구>장소>시간'과 같은 위계로 실현된다고 주장한 반면, Jackendoff (1972)는 의미역 위계 조건(Thematic Hierarchy Condition)을 '행위자 $>$ 장소 $=$ 원천 $=$ 도달점 $=$ 도구 $>$ 대상'으로 설 명하였다. Givón (1983)은 능동 단문에서 주어 또는 목적어로 얼마 나 실현되느냐에 따라 의미역의 계층을 '행위자>여격=수혜자> 피동자 $>$ 장소 $>$ 도구 $=$ 동반격 $>$ 수단'으로 설명하였다. 이처럼 학 자들마다 의미역의 위계를 다르게 설정하지만, 공통점은 문장 내 에서 명사구 간 상위를 차지하는 의미역이 있다는 점이다(Kim \& Woo, 2007). Fillmore (1968)는 전형적 어순 문장에서의 의미역 위 계가 '행위자(agent) >도구(instrument) $>$ 대상(theme) >수혜자 (receiver)'라고 하며, 행위자가 없을 경우에는 도구, 대상, 수혜자 의 미역 순으로 주어 자리에 위치한다고 한다. 피동자(patient), 장소 (location), 도달점(goal)과 같은 다른 의미역은 전형문에서 갖는 위 계가 학자들마다 달라, 전형적 어순 문장에서 어느 의미역이 상위 에 해당하는지는 불분명하다(Baker, 1992; Carrier-Duncan, 1985; Dik, 1992; Grimshaw, 1990; Jackendoff, 1972; Speas, 1990; Van Valin, 1990).

의미역 처리에서 의미역 위계가 중요한 만큼 의미역과 동사간의 관계도 중요하다. Koenig, Mauner와 Bienvenue (2003)는 동사와 의미역 명사 간의 관계가 필수적(obligatory)인지, 선택적(optional) 인지에 따라 통사 처리에 영향이 있다고 설명하며, 이 둘의 관계가 필수적일수록 통사 처리가 용이하다고 한다. 이는 의미역 명사가 필수적인 논항에 해당하는 것과는 별개로 동사와 의미역 명사 간 의미적인 관련성이 높음을 의미한다. Willits, D’Mello, Duran 그리 고 Olney (2007)도 동사와 의미역 명사간 의미적 관련성이 높을 때
의미적 연관성(semantic association)이 잘 나타난다고 하였으며, 이를 의미역 관련성 효과(thematic-relatedness effect)로 설명하였 다. McRae 등(2005)은 행위자, 대상, 장소, 도구 의미역이 동사와 어 떤 점화효과를 보이는지 살펴보았을 때 모든 의미역에서 유의한 효 과가 나타났다고 하였으며 장소나 도구와 같은 필수 논항이 아닌 수의적 논항의 의미역에서도 동사와 밀접한 관련성이 있음을 보고 하였다.

실어증 환자를 대상으로 한 동사 의미역 연구 중 가장 대표적인 것은 동사 의미역 강화 중재(Verb Network Strengthening Treatment [VNeST]; Edmonds, Nadeau, \& Kiran, 2009)이다. 이들은 동 사를 중심으로 행위자와 대상 의미역을 활용하여 어휘 산출 능력 을 중재하였는데, 그 결과 목표 동사, 목표 동사와 의미적 관련성이 높은 동사, 목표 동사의 의미역에 해당하는 명사까지 산출 능력이 향상되는 일반화 효과가 나타났다. 이 중재를 토대로 한국어 실어 증 환자들에게 실시한 Kwag, Sung, Kim 그리고 Cheon (2014)도 동 일한 결과를 나타냈다. 한편, 동사 의미역 처리에 한국어의 언어학 적 특성이 반영되기도 한다. Jeong과 Sung (2018)은 동사를 제시했 을 때 의미역 유형(행위자, 대상)에 따라 실어증 환자와 정상 성인 간 정반응률을 비교하였는데, 실어증 환자의 정반응률이 유의하게 낮았으며 특히 행위자 의미역에서 더 낮은 것으로 나타났다. 즉, 실 어증 환자들이 정상 성인에 비해 동사 의미역 처리에 어려움을 보 이는 특성은 언어권에 상관없이 보편적으로 나타나는 결과이지만, 대상 의미역보다 행위자 의미역에서 유의하게 더 낮은 정반응률을 나타낸 것은 주어가 빈번하게 생략되는 한국어의 특성에 의한 것 이다(Sung, 2016). Dickey와 Warren (2015)도 실어증 환자들이 의 미역을 처리하는 과정에서 동사 특정 지식(verb-specific knowledge)이 강하게 작용한다고 주장하였다.

이처럼 동사 의미역 처리 과정은 언어권에 따라 다양한 특성을 나타낸다. 여러 선행 연구들에서도 영어와 같이 어순이 중요한 언 어권에서는 실어증 환자들이 동사 의미역 처리에 어순의 영향을 많 이 받은 반면(Caplan, 1983; Caplan \& Futter, 1986; Caplan, Hildebrandt, \& Marshall, 1988; Grodzinsky, 1986; Schwartz, Saffran, \& Marin, 1980), 한국어, 일본어와 같이 상대적으로 어순이 자유로운 언어권에서는 전형성의 영향을 많이 받는 것으로 나타났다(Hagiwara \& Caplan, 1990; Jeong \& Sung, 2018). 또한 한국어는 SubjectObject-Verb (SOV) 구조로 필수 논항인 행위자, 대상뿐만 아니라 도구, 장소와 같은 수의적 논항도 동사보다 선행되는 반면, SubjectVerb-Object (SVO)인 영어권은 의미역에 따라 그 위치가 다르다. 이러한 특성으로 인해 한국어에서의 동사 의미역 중재가 영어권보 다 효과적일 수 있다(Kwag et al., 2014). 또한, 한국어와 같은 굴절어 
(inflectional language)의 경우, 동사뿐만 아니라 명사구 자체의 특 성, 어미, 조사도 의미역을 부여하는데 기여한다(Kim \& Woo, 2007). 특히 한국어에서는 조사가 논항 관계를 표면적으로 표지하 고 의미역 정보를 포함하고 있어 조사의 사용이 중요하다(Han, 2018; Kwon, 1989; Sohn, 2001). Sung (2017)은 정상 청년과 노년에 게 전형성(전형, 비전형)과 문장 유형(능동, 피동)에 따른 조사산출 과제를 실시하였다. 그 결과, 두 집단 모두 비전형문과 피동문에서 낮은 정반응률을 보여, 비전형적이고 복잡한 문장을 처리할 때 인 지적 부담(cognitive load)이 증가하는 것으로 나타났으며, 특히 노 년층에서 그 부담이 가중되는 것으로 나타났다. 이는 한국어가 자 유 어순(free-word order) 체계를 가지고 있지만 SOV 어순을 더 많 이 사용하기 때문에(Im, 2007; Nam, 1988) 빈도 효과(frequency effect)에 따라(Crocker \& Brants, 2000) 전형성 효과가 나타난 것이 다. 이와 같은 특성들로 인해 동사 의미역 처리 과정은 보편적인 언 어학적 특징보다 언어 특정적인(language-specific) 요인이 더 강하 게 작용할 것으로 보인다(Dickey \& Warren, 2015).

한편, 경도인지장애 환자의 격조사 처리 능력을 살펴본 Hyun, Sung, Jeong, Kang과 Kim (2013)도 정상 노년과 경도인지장애 환 자 간 통사적 복잡성(홑문장, 겹문장)에 따른 격조사 처리능력을 살펴보았는데, 경도인지장애 환자의 수행력이 모든 문장 유형에서 낮은 수행력을 나타냈고 특히 겹문장에서 더 낮은 것으로 나타났 다. 즉, 인지적 손상이 있는 집단에게 통제된 의미 능력 및 문장 유 형 과제를 제시하였을 때 정상 집단보다 낮은 수행력을 나타낸 것 이다. 언어적 결함이 인지 손상과 관련이 있다는 것은 이미 많은 선 행연구들에서 밝혀진 바 있으며(Hula \& McNeil, 2008; Murray, 2012; Murray \& Kean, 2004), 알츠하이머 치매 환자의 문장 산출 능력을 본 다른 선행연구에서도 알 수 있다(Altmann, 2004; Atmann, Kempler, \& Andersen, 2001; Bates, Harris, Marchman, Wulfeck, \& Kritchevsky, 1995). 이는 문장을 처리할 때, 문장 내 논 항 구조에 맞게 의미역을 파악하여 의미론과 통사론적 형태를 연 결 짓는 능력(mapping)이 필요하여(Saffran, Schwartz, M. F., \& Marin, 1980) 인지적 부담이 가중되기 때문이며(Friederici \& Frazier, 1992), 통합적인 인지 과정을 필요로 하기 때문이다(Carlson \& Frazier, 1983; Carlson \& Tanenhaus, 1988; Rayner et al., 1983; Thompson, 2019). 또한 실어증 환자들이 문장 내에서 명사를 의미 적으로 표상(semantic representation)하는데 어려움을 보이고 의 미역 배열에 손상을 보이며(Webster, Franklin, \& Howard, 2007) 어휘-의미론적 정보(lexical semantic information)에 해당하는 문 법형태소에 어려움을 보이는 것을 통해(Levelt, 1989) 문장 처리 과 정과 인지 능력은 높은 관련성이 있음을 알 수 있다. 따라서 알츠하
이머 치매나 경도인지장애와 병소 부위가 다른 실어증 환자들도 문장 내 격조사 처리에 어려움을 나타낸다(Nam, Yim, Jung, Kim, \& Pyun, 1999).

이처럼 한국어에서 조사는 의미역을 해석하는데 매우 중요한 역 할을 하는데(Sung, 2017) 실어증 환자를 대상으로 한 국내 동사 의 미역 연구는 행위자와 대상에 한정되어 있고(Jeong \& Sung, 2018; Kwag et al., 2014) 조사산출 연구도 조사 유형 별로 분석한 것을 찾 기 어려웠다. 따라서 본 연구는 위 선행연구들을 바탕으로 대상과 같이 필수 논항이 아닌 도구, 장소와 같은 수의적 논항에서도 실어 증 환자의 조사 산출 능력이 어떠한지 살펴보고자 한다. 또한 실어 증 환자의 조사 오류 유형 및 반응을 분석하고 실어증 중증도를 가 장 잘 예측하는 의미역 명사 유형이 무엇인지 살펴보고자 한다. 구 체적인 연구 질문은 아래와같다.

1) 의미역 명사 유형(도구, 장소, 대상)에 따라 조사 산출 과제의 정반응률에서 집단(정상 성인, 실어증) 간 차이가 유의한가?

2) 의미역 명사 유형(도구, 장소, 대상)에 따른 조사 산출 과제에 서 실어증 환자의 조사 오류 유형 및 반응 비율은 어떠한가?

3) 실어증 중증도 $(\mathrm{AQ})$ 를 유의하게 예측하는 의미역 명사 유형 (도구, 장소, 대상)은 무엇인가?

\section{연구방법}

\section{연구대상}

본 연구의 대상자로 수도권에 거주 중인 정상 성인 20 명과 실어 증 환자 20 명을 모집하였으나, 실어증 환자 2 명은 일정 변경으로 인 해 연구 기간 내에 참여가 어려웠다. 따라서 정상 성인 20 명, 실어증 환자 18 명을 대상으로 연구가 진행되었다. 본 연구는 이화여자대학 교 생명윤리위원회의 승인을 받았으며(ewha-202002-0020-01) 모 든 대상자는 연구에 참여하기 전에 연구에 대한 설명을 듣고 동의 서에 서명하였다. 연구 대상자 선정 기준은 다음과 같다. 실어증 환 자는 (1) 좌뇌반구 단일부위로 피질 및 피질하 영역에 뇌졸중으로 기인한 언어장애를 보이는 자, (2) 파라다이스-한국판-웨스턴 실어 증검사 개정판(Paradise-Korean version-the Western Aphasia Battery-Revised, PK-WAB-R; Kim \& Na, 2012)을 통해 실어증으로 분 류된 자, (3) 발병 전 주 손잡이가 오른손잡이인 자, (4) 발병 이전에 뇌 손상 및 기타 신경학적 질환이 없는 자, (5) PK-WAB-R 하위 영 역 중 읽기 영역에서 단어-사물 짝짓기, 단어-그림 짝짓기, 그림-단 어 짝짓기 과제를 모두 정반응하고(Jeong \& Sung, 2018) 문항에서 글자로 제시된 단어를 소리 내어 읽은 자, (6) 연령과 교육수준 차이 가 수행력에 미치는 영향을 최소화하기 위해 초등학교 졸업 이상 
이고 75세 이하인 자(Kang, Chin, Na, Lee, \& Park, 2000), (7) 현재 또는 교정 시력이 정상인 자로 선정하였다.

정상 성인은 (1) 실어증 환자 집단과의 평균 연령 및 교육년수가 일치하는 자, (2) 건강 선별기준(Christensen, Multhaup, Nordstrom, \& Voss, 1991)에 따라 신경학적, 정신적, 두뇌손상 병력이 보 고되지 않은 자, (3) 언어 및 인지적, 신경학적 손상 및 발달적 병력 이 보고되지 않은 자, (4) 한국판 간이 정신 상태 검사(Korean-Mini Mental State Examination [K-MMSE]; Kang, Na, \& Hah, 1997) 점 수가 연령 및 교육년수에 따라 $16 \%$ ile 이상에 해당하는 자(Kang, 2006), (5) PK-WAB-R 하위영역 중 읽기영역에서 단어-실물 짝짓 기, 단어-그림 짝짓기, 그림-단어 짝짓기 과제를 모두 정반응하고 (Jeong \& Sung, 2018) 문항에서 글자로 제시된 단어를 소리 내어 읽 은 자, (6) 연령과 교육수준 차이가 수행력에 미치는 영향을 최소화 하기 위해 초등학교 졸업 이상이고 75세 이하인 자(Kang et al., 2000), (7) 현재 또는 교정 시력이 정상인 자로 선정하였다. 또한 정 상 성인에 60 세 이상이 많이 포함되어, 기본적인 인지, 구어, 기억능 력 등이 정상인지 확인하기 위해 다음과 같은 추가적인 선별검사 를 실시하였다. (1) 서울신경심리검사 2판(Seoul Neuropsychologic Screening Battery-II [SNSB-II]; Kang, Jahang, \& Na, 2012)의 하위 검사인 서울구어학습검사(Seoul Verbal Learning Test, SVLT) 점
수가 연령 및 교육연수에 따라 $16 \%$ ile 이상인 자, (2) 자기보고를 통 해 일상생활을 독립적으로 유지할 수 있는 자로 선정하였다.

집단 간 연령 및 교육년수의 차이가 통계적으로 유의한지 알아보 기 위해 독립표본 $t$ 검정(independent sample $t$ test)을 각각 실시하 였다. 그 결과, 집단 간 연령 및 교육년수의 차이가 통계적으로 유의 하지 않았다. 본 연구에 참여한 대상자 정보는 Table 1에, 실어증 환 자 정보는 Table 2에 제시하였다.

\section{연구과제}

\section{의미역 명사 및 서술어 선정}

본 연구의 조사 산출 과제는 의미역 명사 유형을 도구, 장소, 대상

Table 1. Demographic information of participants

\begin{tabular}{lcccc}
\hline & $\begin{array}{c}\text { Normal } \\
(\mathrm{N}=20)\end{array}$ & $\begin{array}{c}\text { Aphasia } \\
(\mathrm{N}=18)\end{array}$ & $t$ & $p$ \\
\hline Age $(\mathrm{yr})$ & & & -.96 & .343 \\
Mean (SD) & $50.25(13.35)$ & $54.17(11.60)$ & & \\
$\quad$ Range & $30-67$ & $32-69$ & & .239 \\
Education & & & 1.52 & \\
Mean (SD) & $14.55(1.99)$ & $13.39(2.64)$ & & \\
Range & $12-18$ & $6-18$ & & \\
\hline
\end{tabular}

Table 2. Descriptive information of participants with aphasia

\begin{tabular}{|c|c|c|c|c|c|c|c|c|c|c|}
\hline \multirow{2}{*}{ ID } & \multirow{2}{*}{ Age (yr) } & \multirow{2}{*}{ Sex } & \multirow{2}{*}{ Ed (yr) } & \multirow{2}{*}{ YPO } & \multicolumn{5}{|c|}{ PK-WAB-R ${ }^{\mathrm{a}}$} & \multirow{2}{*}{ Type } \\
\hline & & & & & $\mathrm{AO}$ & Fluency & Comprehension & Repetition & Naming & \\
\hline $\mathrm{P} 1$ & 55 & $M$ & 16 & 2 & 84.9 & 6 & 8.85 & 9.2 & 9.4 & Anomic \\
\hline P2 & 52 & $\mathrm{~F}$ & 16 & 3 & 87.6 & 6 & 8.5 & 9.8 & 9.5 & Anomic \\
\hline P3 & 35 & $M$ & 14 & 3 & 90.6 & 6 & 10 & 9.3 & 10 & Anomic \\
\hline P4 & 65 & $\mathrm{M}$ & 12 & 6 & 82.5 & 6 & 8.95 & 8.9 & 9.4 & Anomic \\
\hline P5 & 58 & $\mathrm{~F}$ & 12 & 7 & 88.7 & 9 & 9.55 & 9.4 & 9.4 & Anomic \\
\hline P6 & 69 & $M$ & 6 & 25 & 85.8 & 8 & 8.6 & 10 & 8.3 & Anomic \\
\hline P7 & 57 & $\mathrm{~F}$ & 18 & 4 & 92.1 & 9 & 9.25 & 9.4 & 9.4 & Anomic \\
\hline P8 & 64 & $\mathrm{~F}$ & 12 & 3 & 86.1 & 8 & 8.35 & 9.8 & 8.9 & Anomic \\
\hline Pg & 46 & $\mathrm{M}$ & 14 & 9 & 81.2 & 7 & 8.6 & 8.4 & 8.6 & Anomic \\
\hline P10 & 55 & $\mathrm{M}$ & 16 & 8 & 69.8 & 6 & 8.35 & 5.6 & 8.7 & Conduction \\
\hline P11 & 64 & $\mathrm{M}$ & 13 & 9 & 75.2 & 6 & 9.8 & 6.5 & 8.3 & Conduction \\
\hline P12 & 67 & $\mathrm{M}$ & 12 & 24 & 61.3 & 2 & 8.55 & 7.2 & 5.9 & Broca \\
\hline P13 & 38 & $\mathrm{~F}$ & 12 & 1 & 52.2 & 1 & 9.8 & 0.6 & 8.7 & Broca \\
\hline P14 & 43 & $\mathrm{M}$ & 12 & 2 & 65.8 & 4 & 7.8 & 5.6 & 7.5 & Broca \\
\hline P15 & 59 & $\mathrm{M}$ & 14 & 4 & 31 & 2 & 5.5 & 1.8 & 1.2 & Broca \\
\hline P16 & 68 & $\mathrm{~F}$ & 14 & 30 & 48.7 & 2 & 7.05 & 5.2 & 5.1 & Broca \\
\hline P17 & 32 & $\mathrm{M}$ & 16 & 6 & 50.1 & 2 & 6.25 & 2 & 7.8 & Broca \\
\hline P18 & 48 & $\mathrm{M}$ & 12 & 9 & 64.1 & 4 & 7.75 & 5.2 & 9.1 & Broca \\
\hline
\end{tabular}

Values are presented as mean (SD).

$\mathrm{M}=$ Male; $\mathrm{F}=$ Female; $\mathrm{Ed}=$ Education; $\mathrm{YPO}=$ = Years Post Onset; $\mathrm{AQ}=$ = Aphasia Quotient.

aParadise Korean version-the Western Aphasia Battery-Revised (Kim \& Na, 2012). 
으로 선정하였다. Fillmore (1968)의 의미역 위계에서 행위자 의미 역이 가장 높으나 한국어의 특성상 주어 생략이 빈번하여 행위자 를 제외하였고(Jeong \& Sung, 2018), 그 다음으로 의미역 위계가 높 은 도구와 대상을 선정하였다. 또한 모든 명사 유형을 무생물 명사 로 통제하기 위해 도구 의미역과 위계가 동일한 장소 의미역을 선정 하였다(Fillmore, 1968; Jackendoff, 1972).

2 개의 의미역 명사('도구, 대상' 또는 '장소, 대상')와 1 개의 서술 어를 하나의 자극으로 하여 ‘도구, 대상' 문항 20 개, '장소, 대상' 문 항 20 개, 총 40 문항으로 구성하였다. 도구 의미역에 해당하는 명사 20 개, 장소 의미역에 해당하는 명사 20 개, 대상 의미역에 해당하는 명사 40 개의 선정 기준은 다음과 같다. 모든 명사는 (1) 연세 20세 기 한국어 말뭉치에서 100 이상의 고빈도 및 초고빈도이고(Seo, 1998), (2) 중복되지 않고 과제에서 1 번씩만 제시되었으며, (3) 타당 성 검증에서 도구 의미역 명사에 도구격 조사를, 장소 의미역 명사 에 처소격 명사를, 대상 의미역 명사에 목적격 조사가 $90 \%$ 이상 사 용된 것으로 선정하였다. 서술어는 (1) 정상 성인 20-40대 72명에게 실시한 타당도 검증에서 $80 \%$ 이상 산출된 서술어 중에, (2) 연세 20 세기 한국어 말뭉치에서 100 이상의 고빈도 및 초고빈도인 것으로 선정하였다(Seo, 1998). 의미역 명사 유형(도구, 장소, 대상) 간 어휘 빈도(word frequency) 차이가 유의한지 알아보기 위해 일원배치 분산 분석(one-way between ANOVA)을 실시한 결과, 의미역 명사 유형 간 어휘 빈도 차이가 유의하지 않았다 $\left[F_{(2,77)}=2.436, p=.094\right]$.

\section{실험 자극}

조사 산출 과제는 마이크로소프트 파워포인트 2010 (Microsoft PowerPoint 2010)으로 제작하였으며, 문항의 순서 효과를 배제하 기 위해 역균형화(counterbalance)하였다. ‘도구, 대상' 20 문항 중 10 문항은 '도구’를 첫 번째 명사구에, 나머지 10 문항은 '대상'을 첫 번째 명사구에 제시하였으며, '장소, 대상' 20 문항도 동일하게 10 문 항은 '장소'를 첫 번째 명사구에, 나머지 10 문항은 '대상'을 첫 번째
명사구에 제시하였다. 전체 문항은 무작위순서(randomized)로 배 열하여 제시하였다. 모든 자극은 한 페이지에 한 문항씩 글자로 제 시하였으며 각 의미역 명사 뒤에 올 조사를 빈칸으로 제시하여 도 구 의미역 명사 뒤에 도구격 조사 '-(으)로', 장소 의미역 명사 뒤에 처소격 조사 ‘-에', 대상 의미역 명사 뒤에 목적격 조사 '-을/를'을 적 절하게 넣어 산출하도록 하였다. 예시 문항은 Figure 1에 제시하였 고 전체 문항 목록은 Appendix 1에 제시하였다.

\section{타당도}

의미역 명사에 대한 타당도 검증을 정상 성인 20-40대 72명(1차 23 명, 2 차 29명, 3 차 20명)에게 총 3 차례 실시하였다. '도구, 대상'과 ‘장소, 대상' 의미역 명사만을 제시하여 응답자들이 조사와 서술어 를 자율적으로 사용하여 문장을 만들도록 하였다. 1 차와 2 차 검증 에서 응답자의 $90 \%$ 이상이 선정한 의미역 명사 유형에 따른 조사 를 산출하지 않았을 경우, 해당 문항의 명사를 제외하였으며, 3 차 에 실시한 모든 문항에서 응답자의 $90 \%$ 이상이 선정한 의미역 명 사 유형에 따른 조사를 산출하여 본 실험 자극을 선정하였다. 서술 어는 각 응답 결과 문항에서 $80 \%$ 이상 사용된 것으로 채택하였다.

\section{연구절차}

모든 대상자에게 실험에 대한 동의를 받은 후, 대상자의 집 또는 근처 조용한 공간에서 선별 검사 및 본 연구 과제를 개별적으로 실 시하였다. 연구자의 개인 노트북 화면으로 과제를 실시하였고, 대 상자의 모든 응답은 연구자의 스마트폰(Apple iPhone Xs)으로 녹 음하였다. 대상자가 과제를 충분히 숙지하도록 본 실험 전 연습 문 항을 실시하였다. 연구자는 대상자에게 "먼저 연습 문항을 실시하 겠습니다. 두 개의 명사와 한 개의 서술어가 있습니다. 빈칸에 알맞 은 말을 넣어 말씀해 주세요.”라고 지시문을 들려주었다. 연습 문항 에는 본 실험의 목표 조사를 포함한주격 조사 '-이/가'와 여격 조사 '-에게’가 사용되었다. 연습 문항에서 대상자가 오반응을 보인 경
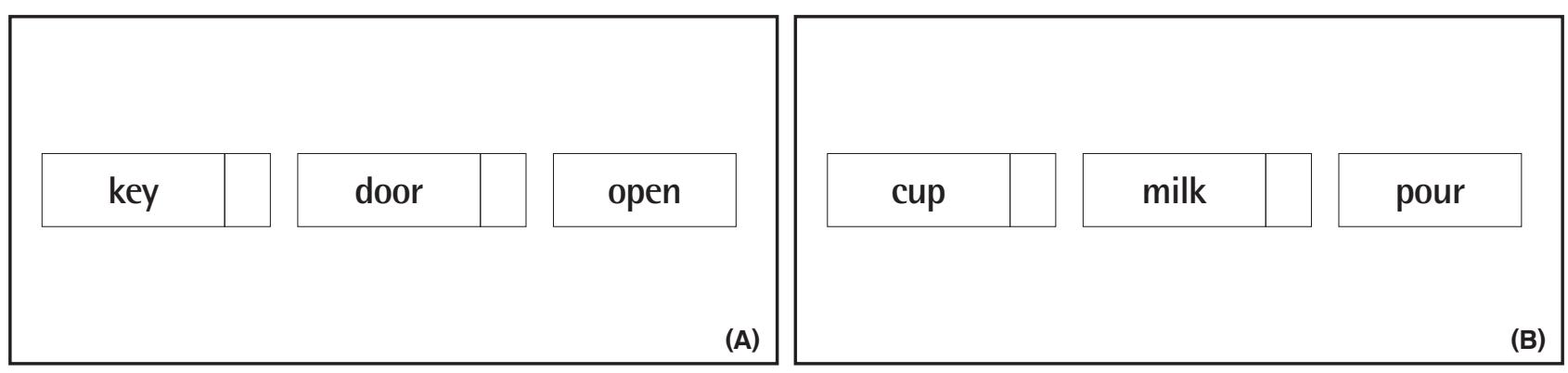

Figure 1. Examples of the case maker assignment. (A) Instrument-theme nouns of thematic roles. (B) Location-theme nouns of thematic roles. 
우, 연구자는 피드백을 주었고 대상자가 모든 조사를 최소 한 번 이 상 산출한 후 본 실험에 참여하도록 하였다. 또한 실어증 환자 중 유 창성이 낮은 경우, 조사 카드를 글자로 제시하여 연습 문항에서 충 분히 숙지하도록 하였다.

\section{자료분석}

\section{정반응률(Accuracy)}

모든 대상자의 녹음 파일은 연구자가 전사하였으며, 대상자의 최 종 반응으로 채점하여 각 의미역 명사별로 정반응률을 산출하였 다. 정반응 수는 도구 의미역 명사에 도구격 조사 '-(으)로'를, 장소 에 처소격 조사 '-에'를, 대상에 목적격 조사 '-을/를'을 산출한 경우 에 각각 1 점씩 부여하였고, 대상자가 목표 조사 이외의 조사를 산 출하거나 생략한 경우에는 오반응으로 간주하여 0 점으로 처리하 였다. 대상자가 산출한 조사에 대해서만 정반응 여부를 판단하였 으며, 제시된 단어 자극을 정확하게 읽는지에 대한 채점은 실시하 지 않았다. 조사 산출 정반응률(\%)은 (각 의미역 명사에서 정반응 한 문항 수/각 의미역 명사문항 수 $) \times 100$ 으로 산출하였다.

\section{오류분석}

실어증 환자의 조사 오류 유형은 대치, 생략, 알 수 없음(Don't Know, DK)으로 구분하였으며, 대치된 조사를 오류 반응으로 분석 하였다. 본 실험 과제 전 연습 문항을 통해 목표 조사와 주격 및 여 격 조사를 충분히 산출하였기에 조사 오류 유형 중 $\mathrm{DK}$ 에 해당하 는 대상자는 없었으며, 착어는 정반응으로 간주하였다. 예를 들어, '연필로' 대신에 ‘연필이'라고 산출했을 경우, 조사 오류 유형은 '대 치’이고, 조사 오류 반응은 ‘주격조사'이다.

오류 분석은 각 의미역 유형 별로 다음과 같이 산출하였다. 조사 오류 유형 비율(\%)은 (총 조사 오류 유형 수/총 조사 오류 수 $) \times 100$ 으로 산출하였고, 조사 오류 반응 비율(\%)은 (총 조사 오류 반응 수/총 조사 오류 수) $\times 100$ 으로 산출하였다. 의미역 명사 유형별 조 사 오류 유형 및 반응 예시는 Appendix 2에 제시하였다.

\section{통계적 처리}

본 연구는 IBM SPSS statistics version 26.0 (Statistics Package for the Social Science, version 26.0) for Windows 프로그램을 사용 하여 분석하였다. 먼저 집단 간 의미역 명사 유형(도구, 장소, 대상) 에 따른 조사 산출 정반응률에 유의한 차이가 있는지 알아보기 위 해 이원혼합분석(two-way mixed ANOVA)을 실시하였다. 또한 의 미역 명사 유형별 정반응률이 실어증 중증도와 어떤 상관관계를 보 이는지 살펴보기 위해 Pearson 상관계수를 실시하였다. 마지막으
로 실어증 중증도(AQ)를 유의하게 예측하는 의미역 명사 유형을 알아보기 위해 단계적 회귀 분석(stepwise regression analysis)을 실시하였다.

\section{연구결과}

\section{집단 간 의미역 명사에 따른 조사 산출 정반응률}

의미역 명사 유형에 따른 집단 간 조사산출 정반응률 차이를 알 아보기 위해 이원혼합분석(two-way mixed ANOVA)을 실시하였 다. 그 결과, 집단에 대한 주효과가 통계적으로 유의하였다 $\left(F_{(1,36)}=\right.$ $28.419, p<.0001)$. 즉, 실어증 환자 $(\mathrm{M}=59.35, \mathrm{SD}=34.26)$ 가 정상 성인 $(M=97.58,4.91)$ 보다 의미역 명사 유형에 따른 조사 산출 정반 응률이 유의하게 낮은 것으로 나타났다.

의미역 명사 유형에 따른주효과가 통계적으로 유의하였다 $\left(F_{(2,72)}=\right.$ $11.522, p<.0001)$. 도구 의미역 명사에서의 정반응률이 가장 낮았고 $(\mathrm{M}=72.21, \mathrm{SD}=35.17)$, 대상에서 가장 높았다 $(\mathrm{M}=83.38, \mathrm{SD}=26.90)$. 이에 대해 Bonferroni 사후검정을 실시한 결과, 도구와 장소 의미역 명사 간 정반응률 차이가 통계적으로 유의하였고( $p=.031)$, 도구와 대상 의미역 명사 간 정반응률 차이도 통계적으로 유의하였다 $(p=.0001)$. 반면, 장소와 대상 의미역 명사 간 정반응률 차이는 통 계적으로 유의하지 않았다 $(p=.236)$.

의미역 명사 유형과 집단 간 이차 상호작용이 통계적으로 유의하 였다 $\left(F_{(2,72)}=4.671, p<.05\right)$, 의미역 명사 유형과 집단 간 이차 상호 작용 효과가 유의한 지 검증하기 위해 LMATRIX와 MMATRIX 로 사후검정을 실시한 결과, 도구와 대상 의미역 명사에서 집단 간 차이가 통계적으로 유의하였으나 $(p=.003)$, 도구와 장소 의미역 명 사에서 집단 간 차이는 통계적으로 유의하지 않았고 $(p=.110)$, 장소 와 대상 의미역 명사에서 집단 간 차이도 통계적으로 유의하지 않 았다 $(p=.202)$. 즉, 실어증 환자는 정상 성인보다 도구 의미역 명사 에서 도구격 조사를 산출할 때, 대상에서 목적격 조사를 산출할 때 보다 수행력이 유의하게 감소한 것으로 나타났다. 집단 간 의미역 명사 유형에 따른 조사 산출 정반응률 분석 결과는 Table 3 과 Figure 2에 제시하였다.

\section{실어증 집단의 조사 오류 유형 및 반응 비율}

조사 산출 과제에서 실어증 환자의 오류는 약 $38 \%$ 로, 그 중 약 $80 \%$ 는 대치 오류였다. 도구 의미역 명사에서의 도구격 조사는 목 적격 조사로 가장 많이 대치되었고(34.07\%), 처소격 조사(32.42\%), 주격 조사(13.74\%)가 그 뒤를 이었다. 장소 의미역 명사에서의 처소 격 조사도 목적격 조사로 가장 많이 대치되었으며(39.42\%), 도구격 
Table 3. Results of two-way mixed ANOVA

\begin{tabular}{lcccc}
\hline & Sum of square & Degree of freedom & Mean square & $F$ \\
\hline Group & 41541.523 & 1 & 41541.523 & $28.419^{* * *}$ \\
Error & 52622.731 & 36 & 1461.743 & $11.522^{* * *}$ \\
Thematic role noun type & 2466.511 & 2 & 1233.255 & .000 \\
Thematic role noun type & & & 499.922 & .000 \\
x Group & 999.844 & 2 & 107.032 & $.671^{*}$ \\
Error & 7706.296 & 72 & & .012 \\
\hline
\end{tabular}

${ }^{*} p<.05,{ }^{* * *} p<.001$.

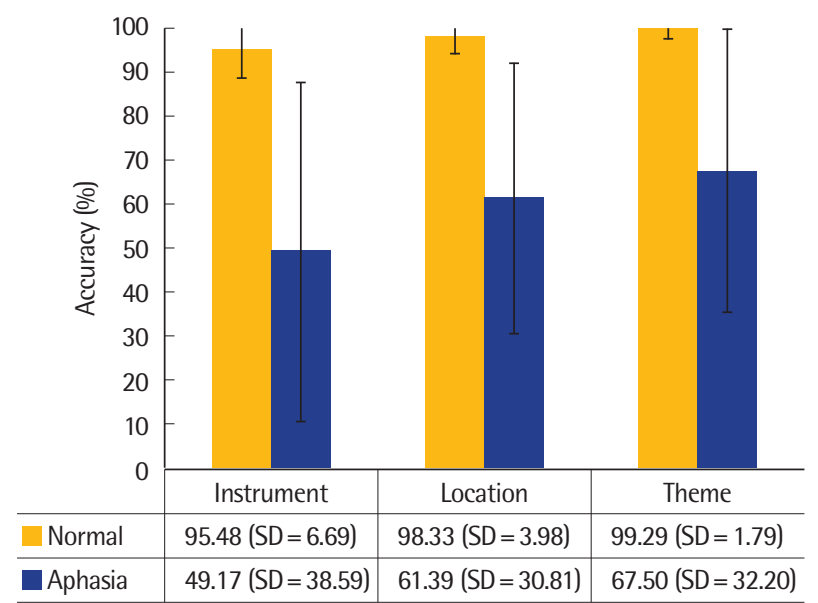

Figure 2. Accuracy of noun types of thematic roles between groups.

조사(19.71\%), 주격 조사(10.22\%)가 그 뒤를 이었다. 마지막으로 대 상 의미역 명사에서의 목적격 조사는 처소격 조사로 가장 많이 대 치되었고(29.13\%), 도구격 조사(22.61\%), 주격 조사(16.52\%)가 그 뒤를 이었다. 실어증 환자의 의미역 명사 유형에 따른 조사 산출 오 류 반응 비율을 Figure 3에 제시하였다.

\section{실어증 중증도와 의미역 명사 유형 간 상관관계 및 회귀분석}

조사 산출 과제에서 의미역 명사 유형 별 정반응률과 실어증 중 증도 간 상관관계를 살펴보기 위하여 Pearson 상관계수를 실시하 였다. 그 결과, 도구 의미역 명사 $(r=.609, p=.001)$, 장소 의미역 명사 $(r=.694, p=.001)$, 대상 의미역 명사 $(r=.676, p=.002)$ 모두 실어증 중증도와 강한 정적 상관관계를 보였다. 상관관계 결과는 Table 4 에 제시하였고 실어증 중증도에 따른 의미역 명사 유형별 정반응률 산포도를 Figure 4에 제시하였다.

의미역 명사 유형 중 실어증 중증도를 가장 잘 예측하는 변인을 살펴보기 위해 단계적 회귀분석(stepwise regression analysis)을 실 시하였다. 다중공선성 확인 결과, Variance Inflation Factor (VIF) 가 도구 의미역 명사 2.437 , 장소 의미역 명사 1.000 , 대상 의미역 명 사 3.638로 나타나 다중공선성이 없는 것으로 판단되었다. 단계적

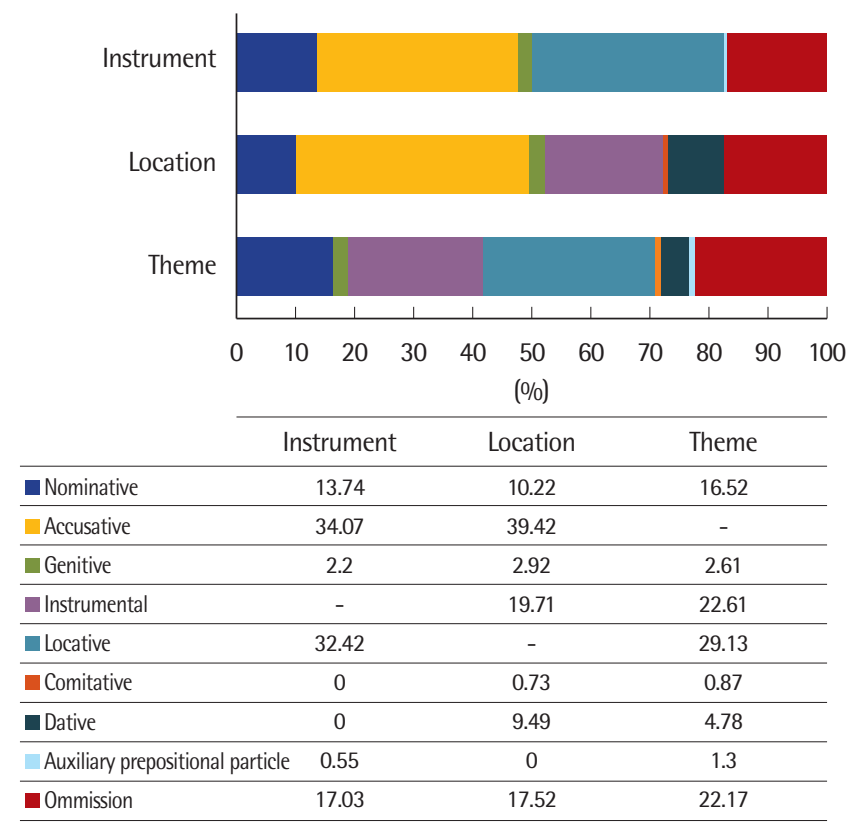

Figure 3. Percentage of errors in each noun type of thematic roles in aphasia.

회귀분석 결과, 장소 의미역 명사가 실어증 중증도를 가장 잘 예측 하는 것으로 나타났다 $\left(F_{(1,17)}=14.881, p<.01, R^{2}=.482\right)$. 즉, 장소 의 미역 명사가 실어증 환자의 중증도를 약 $48.2 \%$ 예측하는 것으로 나 타났다. 그 결과는 Table 5에 제시하였다.

\section{논의 및 결론}

본 연구는 정상 성인과 실어증 환자를 대상으로 조사 산출 과제 를 실시하여 의미역 명사 유형(도구, 장소, 대상)에 따라 조사 산출 정반응률에서 집단 및 의미역 명사 유형 간 차이가 있는지 살펴보 았다. 그 결과, 실어증 환자는 정상 성인보다 모든 의미역 명사 유형 에서 낮은 정반응률을 보였으며, 실어증 환자가 동사 의미역 처리에 어려움을 보인다는 선행연구와 일치하는 결과를 나타냈다(Carlson \& Tanenhaus, 1988; Rayner et al., 1983). 본 연구의 조사 산출 
Table 4. Result of Pearson correlation coefficients between noun types of thematic roles and the aphasia quotient

\begin{tabular}{lccc}
\hline & Instrument & Location & Theme \\
\hline Aphasia quotient & $.609^{* * *}$ & $.694^{* *}$ & $.676^{* *}$ \\
\hline
\end{tabular}

${ }^{* *} p<.01$.

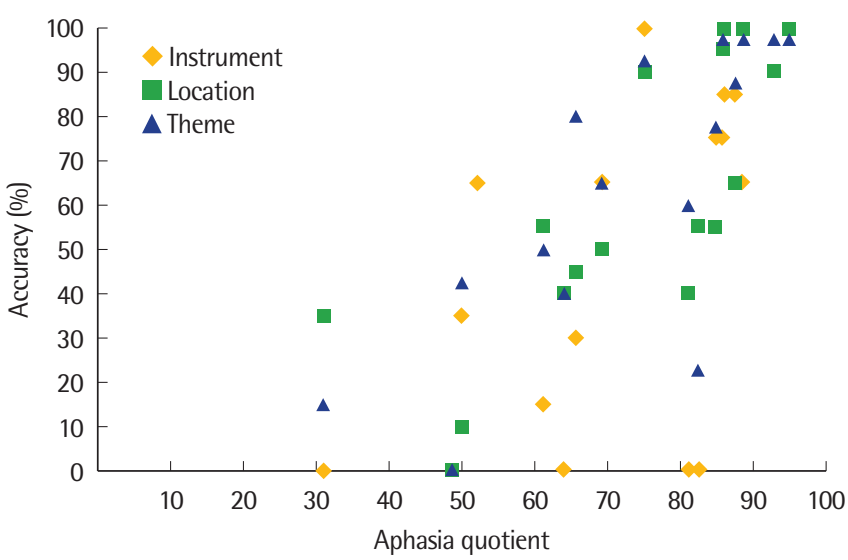

Figure 4. Correlation between percentage of errors in each noun type of thematic roles and the aphasia quotient.

과제는 1 개의 서술어와 2 개의 의미역 명사를 토대로 의미역 처리라 는 복잡한 언어적 처리 과정이 이루어지고(Friederici \& Frazier, 1992; Jeong \& Sung, 2018) 의미 체계 내에서 어휘 정보를 찾아야 하는 것이었다. 이 과정에는 통사론과 의미론적 형태를 동시적으 로 연결하는 통합적인 인지 처리 과정이 필요하고(Carlson \& Frazier, 1983; Carlson \& Tanenhaus, 1988; Rayner et al., 1983; Saffran et al., 1980), 문장 처리 시 인지적 부담이 가중된다. 이로 인해 실어 증 환자들이 정상 성인에 비해 낮은 정반응률을 보인 것으로 해석 되며, 본 연구 결과는 여러 선행연구의 결과들과도 일치한다(Altmann, 2004; Altmann et al., 2001; Bates et al., 1995; Hyun et al., 2013). 또한 Hwang (2003) 연구에 따르면 한국 실어증 환자들은 영 어권 환자들과 달리 조사 단서를 가장 많이 활용하여 문장을 이해 한다고 한다. 하지만 본 연구 과제는 조사 단서 없이 의미역 명사와 서술어만을 활용하여 논항 관계를 파악하고 통사적 구조를 완성 해야 했기에 실어증 환자들이 어려움을 겪은 것으로 보인다.

의미역 명사 유형(도구, 장소, 대상) 간 차이도 유의한 것으로 나 타났다. 이 결과는 도구 의미역에서의 도구격 조사와 장소에서의 처소격 조사 간의 정반응률 차이와, 도구에서의 도구격 조사와 대 상에서의 목적격 조사 간의 정반응률 차이가 유의하게 큰 것에서 기인하였다. 대상 의미역의 경우, 의미역 위계가 높고 통사적으로 서술어에 가깝게 위치하며(Dickey \& Warren, 2015; Jeong \& Sung,
Table 5. Result of stepwise regression between noun types of thematic roles and aphasia quotient

\begin{tabular}{cccc}
\hline & $B(S E)$ & $R^{2}$ & $p$ \\
\hline Location & $.408(.106)$ & .482 & $.001^{* *}$ \\
\hline
\end{tabular}

${ }^{* *} p<.01$.

2018) 대상 의미역 명사와 결합하는 목적격 조사의 사용 빈도가 조 사 중 가장 높은 것에 따라(Seo, 1998), 대상 의미역 명사에서의 목 적격 조사 정반응률이 가장 높게 나타난 것으로 해석할 수 있다. 한 편, 도구와 장소는 비슷한 의미역 위계에 해당하는데(Jackendoff, 1972) 도구 의미역에서의 도구격 조사 정반응률보다장소 의미역에 서의 처소격 조사 정반응률이 유의하게 높게 나타났다는 점이 흥 미롭다. 도구성(instrumentality)을 연구한 연구자들의 연구 결과 에 따르면, 명칭 실어증 환자들은 도구 동사(instrumental verbs)가 비도구 동사(non-instrumental verbs)보다 수행률이 높았는데, 이 는 도구 동사가 구체적인 명사, 즉 도구 명사를 더 잘 연상시키기 때 문이라고 설명하였다(Bastiaanse, 1991; Jonkers \& Bastiaanse, 1996, 2007; Park, Goral, Verkuilen, \& Kempler, 2013). 이러한 맥락으로 볼 때, 명사와 서술어 간 의미적 관련성이 높음에도 불구하고 실어 증 환자들이 해당 명사에 적절한 조사를 산출하는 데 어려움을 나 타낸 것은 의미역 처리 자체에서의 어려움보다 적절한 조사를 산출 하는 것에 어려움이 있기 때문으로 해석할 수 있다(Koenig et al., 2003; Willits et al., 2007). 즉, 본 연구에서 실어증 환자들이 도구 의 미역에서의 정반응률이 낮게 나타난 것은 도구격 조사 산출에 어 려움이 있는 것으로 해석할 수 있다. 이는 문법형태소에 어려움이 있다는 국내외 선행연구들과 일치하는 결과이며(Brookshire, 2007; Bradley, Garrett, \& Zurif 1980; Lee, Kim, Seo, \& Kim, 2009; Park \& Choi, 2011; Miceli, Silveri, Romani, \& Caramazza, 1989), 외국 연구에서 도구격과 처소격 전치사구를 비교한 연구 결과와도 비슷 한 맥락을 가진다(Ferretti, McRae, \& Hatherell, 2001).

한편, 장소와 대상 의미역 간 선행 순서에 따른 문장 전형성이 학 자들마다 달라(Baker, 1992; Carrier-Duncan, 1985; Dik, 1997; Grimshaw, 1990; Jackendoff, 1972; Speas, 1990; Van Valin, 1990), 본 연구에서는 전형성에 따라 대상자들의 반응을 통계적으로 분 석하지 않았다. 그러나 의미역 명사 제시 순서에 따라 전형적인 문 장이 있는 것으로 나타났다. 정상 성인과 실어증 환자 모두 '장소-대 상'보다 '대상-장소' 순으로 의미역 명사를 제시했을 때 더 높은 정 반응률을 나타냈다. 다시 말해, 정상 성인은 '장소-대상' 순에서의 정반응률 $(\mathrm{M}=97, \mathrm{SD}=7.33)$ 보다 '대상-장소' 순에서의 정반응률 $(\mathrm{M}=99, \mathrm{SD}=3.08)$ 이 더 높았고, 실어증 환자도 '장소-대상' 순에서 
의 정반응률 $(\mathrm{M}=51.67, \mathrm{SD}=39.74)$ 보다 '대상-장소' 순에서의 정반 응률 $(\mathrm{M}=54.44, \mathrm{SD}=34.10)$ 이 더 높았다. 이는 Speas (1990), Baker (1992), Carrier-Duncan (1985)의 주장과 일치하며, 본 연구에서는 '대상-장소' 순으로 의미역 명사가 제시된 문장이 더 전형적인 것으 로 나타났다. 본 연구 결과를 토대로 한국어에서 장소 의미역이 문 장에서 어떤 위치에 오는 것이 전형적인지는 일반화하기에 어려움 이 있지만, 굴절어인 한국어에서 의미역 제시 순서가 문장 이해 및 산출에 중요한 영향을 미칠 수 있다. 따라서 후속 연구에서 추가적 인 분석이 필요할 것으로 보인다. 한편, ‘도구, 대상' 의미역 명사에 서는 정상 성인 및 실어증 환자 모두 의미역 위계 및 전형성과 일치 하는 것으로 나타났다(Fillmore, 1968; Jackendoff, 1972).

의미역 명사 유형 별 조사 오류 유형 및 반응 비율을 분석한 결 과, 전체 오류 유형 중 대치 오류가 $80.62 \%$, 생략 오류가 $19.38 \%$ 로, 본 연구에 참여한 실어증 환자는 대치 오류가 약 4 배 많은 것으로 나타났다. 이는 한국어와 같은 굴절어에 해당하는 핀란드어, 헝가 리아어, 체코어 등에서 실시한 실어증 환자들의 조사 산출 연구와 일치하는 결과였다(MacWhinney, Osman-Sagi, \& Slobin, 1991; Marková \& Cséfalvay, 2010; Slobin, 1991). 조사가 논항에 격을 표 지하고 의미역을 부여하며 문법적인 기능뿐만 아니라 그 자체에 의 미를 포함하는 특성으로 인해 굴절어에서는 생략보다는 대치 오류 가 두드러지는 것이다.

각 의미역 명사 유형 별 조사 오류를 분석한 결과, 첫째, 도구 의 미역 명사에 결합하는 도구격 조사는 목적격 조사로 대치되는 오 류가 가장 높았고(34.07\%) 처소격 조사로 대치되는 오류가 그 뒤를 이었다(32.42\%). 도구 의미역 명사의 경우, 그 기능이 명확하기 때 문에 의미역 처리가 적절하게 이루어졌다면 도구격 조사를 산출해 야 한다. 하지만 본 연구에서 실어증 환자들이 도구격 조사 산출에 어려움을 보였으며, Dragoy 등(2016)에서 실어증 환자들이 도구 의 미역 명사를 서술어와 제대로 연관 짓는 것에 어려움이 없더라도 도구격 조사를 산출하는 것에 어려움을 보였다고 한 연구 결과와 일치한다. 반면, 처소격 조사로 대치하는 오류가 높게 나타난 것은 대상 의미역과 달리 도구와장소 의미역이 비슷한 위계를 가지고 있 고 논항 구조 상으로도 수의적인 논항이기 때문에 실어증 환자들 이 수의적 논항에 결합하는 부사격 조사 중 가장 빈도가 높은 처소 격 조사로 대치하는 오류를 보인 것으로 해석할 수 있다(Friederici, 1982; Seo, 1998). 둘째, 장소 의미역 명사에 결합하는 처소격 조사 는 목적격 조사로의 대치가 가장 높았다(39.42\%). 실어증 환자들이 장소 의미역 명사 뒤에 목적격 조사를 많이 사용한 이유는 대상 의 미역 위계가 높기 때문이거나(Blake, 2001; Caha, 2009; Fillmore, 1968), 함께 제시된 대상 의미역 명사와의 논항 관계를 제대로 해석
하지 못하였거나, 서술어가 제공하는 의미역 정보를 제대로 해석하 지 못한 것으로 볼 수 있다(Friederici \& Frazier, 1992; Jeong \& Sung, 2018). Marková와 Cséfalvay (2010) 연구에서 슬로바키아어 실어증 환자들에게 조사를 활용하여 문장을 완성하도록 하였을 때, 브로카 환자들이 소유격, 도구격, 처소격 조사를 주격 또는 목 적격 조사로 대치하는 오류를 약 $28 \%$ 보이는 것과 비슷한 결과를 나타냈다. 마지막으로 대상 의미역 명사에 결합하는 목적격 조사 는 처소격 조사로의 대치가 가장 높았다(29.13\%). 이는 대상 의미역 의 위계가 높고 서술어 앞에 대상 의미역이 오는 것이 전형적이기 때문에(예: A로 B를 붙이다.)(Blake, 2001; Caha, 2009; Fillmore, 1968) 제시된 두 의미역 명사간 의미적 위계를 찾지 못한 환자들이 비전형으로 제시된 문장(예: $\mathrm{B}$ 를 $\mathrm{A}$ 로 붙이다.)에서도 전형 어순의 문장처럼 산출했을 가능성이 있다. 즉, 두 의미역 명사간 관계를 적 절하게 파악하지 못했으나 전형성에 따라 대상 의미역에 목적격 조 사를 산출했을 경우, 나머지 한 의미역에는 조사중 가장 빈도가 높 은 처소격 조사를 산출했을 가능성이 높은 것이다(Seo, 1998).

실어증 중증도를 가장 잘 예측하는 의미역 명사 유형이 무엇인지 살펴본 결과, 장소 의미역 명사가 $48.2 \%$ 로, 실어증 중증도를 가장 잘 예측하는 변인으로 나타났다. 장소 의미역이나 처소격 조사를 실어증 중증도와 직접적으로 언급한 선행연구를 찾을 수는 없었으 나, 여러 선행연구들을 통해 둘의 관계를 유추해 볼 수 있었다. 첫 째, Bek, Blades, Siegal과 Varley (2010)는 중도 실문법증 실어증 환 자와 전실어증 환자의 공간 인식 능력을 연구하였는데, 중증 실어 증 환자들이 정상 성인과 유사한 공간 지남력을 보이는 것으로 나 타났다. 즉, 중증도가 심한 실어증 환자들도 공간 인식 능력이 상당 히 보존되어 있는 것으로 나타났다. 이러한 특성을 토대로 볼 때, 실 어증 환자들이 장소 의미역 처리 시 다른 의미역에 비해 비교적 적 절하게 파악하였으나, 언어에 대한 어려움의 정도, 즉 실어증 중증 도에 따라 장소 의미역 정반응률에서 차이가 나타난 것으로 보인 다. 인지적 자원(cognitive resource)이 한정되어 있기 때문에(Caplan \& Waters, 1999; Linebarger, Schwartz, \& Saffran, 1983) 중도 (severe) 실어증 환자들보다 언어 능력이 높은 경도(mild) 실어증 환 자들이 의미역 명사에 적절한 조사를 탐색하는데 인지적 부담이 적었을 것이고, 상대적으로 의미역 간 관계를 파악하는데 에너지 를 많이 쏟는 중도 실어증 환자들이 더 어려움을 보였을 것으로 해 석된다.

둘째, 실어증 환자들이 빈도 효과(frequency effect)에 의해 어휘 인출(lexical retrieval)에 영향을 많이 받는다는 것은 여러 선행연 구들에서 밝혀진 바 있다(Kittredge, Dell, Verkuilen, \& Schwartz, 2008; Knobel, Finkbeiner, \& Caramazza, 2008; Nickels \& Howard, 
1994; Nozari, Kittredge, Dell, \& Schwartz, 2010). Kittredge 등 (2008)은 어휘 빈도와 음운 및 의미 오류 간의 상관관계를 연구하 였는데, 고빈도 어휘일수록 실어증 환자들의 음운 및 의미적 오류 가 낮았으며, 의미적 오류가 특히 더 낮았다고 보고하였다. 또한 Laiacona, Luzzatti, Zonca, Guarnaschelli과 Capitani (2001)도 실 어증 환자들의 이름대기 능력을 시각적(visual), 의미론적(semantic), 어휘적(lexical) 요인으로 구분하여 살펴본 결과, 어휘적 요인 즉, 어휘 빈도와 이름 일치도(name agreement)가 가장 많은 영향 을 미친다고 보고하였다. 한국어에서 장소 의미역과 처소격 조사가 아동의 언어 발달 과정에서 일찍 출현하는 조사에 해당하고(Cho, 1982; Slobin, 1973), 전체 조사 중 처소격 조사의 어휘 빈도가 수의 적 논항에 오는 조사 중에서 가장 높기 때문에(Seo, 1998), 장소 의 미역 명사가 실어증 중증도를 가장 잘 예측한 것으로 해석된다. 대 상 의미역에서의 목적격 조사가 전체 조사에서 가장 높은 빈도를 차지하기는 하나, 중도 실어증 환자들 중에서도 대상 의미역에서 높은 정반응률을 보인 경우가 있었다. 이는 대상 의미역이 필수 논 항에 해당하기 때문에 중도 실어증 환자들 중에서도 높은 수행력 을 나타낸 것으로 보인다. 따라서 본 연구에서는 수의적 논항 중 사 용 빈도가 가장 높은 장소 의미역 명사가 실어증 중증도를 가장 잘 예측하는 변인으로 나타났다.

의미역 명사 유형 별로 실어증 환자의 정반응률을 본 조사 산출 과제는 여러 측면에서 임상적 시사점을 가진다. 첫째, 과제 제작 및 실시가 간편하다. 의미역에 따라 명사 및 서술어를 선정하고 글자로 제작할 수 있으며, 그림 자극을 별도로 만들지 않아도 된다. 실시 시 간도 10 분 내외이므로, 병원이나 사설 치료실 등에서 한 세션 내에 실시할 수 있다는 장점이 크다. 둘째, 다양한 의미역 유형으로 임상 에서 평가 및 중재로 실시할 수 있다. 본 연구에서는 도구, 장소, 대 상으로만 의미역 유형을 선정하였으나, 이 외에도 수혜자, 피동자, 도달점 등으로 다양하게 실시할 수 있다. 셋째, 실어증 환자의 언어 능력을 평가하기 위한 심층검사(deep test)로 사용될 수 있다. 도구, 장소, 대상 의미역 명사 모두 실어증 중증도와 높은 상관관계를 보 였기 때문에 실어증 환자들의 의미역 처리 능력을 평가할 수 있으 며, 중재로도 다양하게 활용할 수 있을 것으로 생각된다.

본 연구에서 제언하는 향후 연구 방향은 다음과 같다. 첫째, 본 연구는 문장 내 의미역 명사 제시 순서에 따른 정반응률을 통계적 으로 분석하지 않고, 제시 순서를 역균형화하여 순서 효과를 배제 하는 것에만 그쳤다. 후속 연구에서는 의미역 명사 유형 별 문항 수 를 늘려, 의미역 명사 제시 순서에 따른 전형성 효과를 보는 것이 필 요하다. 둘째, 본 연구는 의미역 명사 유형 별로 정반응률을 분석하 는 데 그쳤으며, 한 문장 내에서 의미역 오반응 수에 따른 해석이 이
루어지지 않았다. 한 문장에서 의미역 오반응 수를 분석했을 때 그 결과가 통계적으로 유의하지는 않았으나, 두 의미역 모두 같은 조 사를 사용한 대상자가 있었고 이러한 경우, 대상자가 의미역 관계 를 적절하게 파악했다고 보기 어려운 부분이 있다. 하지만 본 연구 가 오프라인(off-line) 과제로 실시되어 이를 해석하는 데에는 한계 가 있었다. 따라서 후속 연구에서는 실시간 처리 과정(online processing)을 볼 수 있는 사건관련전위(event-related potential, ERP) 나 아이트래킹(eye-tracking) 과제로 실시되는 것이 필요하다. 즉, 실시간 처리 과정을 살펴볼 때, 실어증 환자가 의미역 관계를 적절 하게 파악하는지를 구체적으로 해석할 수 있을 것으로 보인다. 셋 째, 본 연구는 의미역 명사 유형이 도구, 장소, 대상에 한정되어 있고 도구와 장소 의미역에 대한 연구는 부족한 실정이다. 따라서 연구 결과를 일반화하기에는 어려움이 있을 수 있으므로, 후속 연구에 서 다양한 의미역과 논항 수로 실시한다면 더 자세한 결과를 도출 할수 있을 것이다.

\section{REFERENCES}

Altmann, L. J. P. (2004). Constrained sentence production in probable Alzheimer disease. Applied Psycholinguistics, 25(2), 145-173.

Altmann, L. J., Kempler, D., \& Andersen, E. S. (2001). Speech errors in Alzheimer's disease: reevaluating morphosyntactic preservation. Journal of Speech, Language, and Hearing Research, 44(5), 1069-1082.

Baker, M. (1992). Thematic conditions on syntactic structures: evidence from locative applicatives. In I. M. Roca (Ed.), Thematic structure: Its role in grammar (pp. 23-46). Dordrecht, Netherland: Foris Publication.

Bastiaanse, R. (1991). Retrieval of instrumental verbs in aphasia: an explorative study. Clinical Linguistics and Phonetics, 5(4), 355-368.

Bates, E., Harris, C., Marchman, V., Wulfeck, B., \& Kritchevsky, M. (1995). Production of complex syntax in normal ageing and Alzheimer's disease. Language and Cognitive Processes, 10(5), 487-539.

Bek, J., Blades, M., Siegal, M., \& Varley, R. (2010). Language and spatial reorientation: evidence from severe aphasia. Journal of Experimental Psychology: Learning, Memory, and Cognition, 36(3), 646-658.

Blake, B. (2001). Case. Cambridge, MA: Cambridge University Press.

Bradley, D. C., Garrett, M. E., \& Zurif, E. B. (1980). Syntactic deficits in Broca's aphasia. In D. Caplan (Ed.), Biological Studies of Mental Processes. Cambridge, MA: MIT Press.

Brookshire, R. H. (2007). Introduction to neurogenic information communication disorder (7th ed.). St. Louis, MO: Mosby. 
Caha, P. (2009). The nanosyntax of case (doctoral dissertation). University of Tromsø, Tromsø, Norway.

Caplan, D. (1983). A note on the "word order problem" in agrammatism. Brain and Language, 20(1), 155-165.

Caplan, D., \& Futter, C. (1986). Assignment of thematic roles to nouns in sentence comprehension by an agrammatic patient. Brain and Language, 27(1), 117-134.

Caplan, D., Hildebrandt, N., \& Marshall, J. C. (1988). Disorders of syntactic comprehension. Cambridge, MA: MIT Press.

Caplan, D., \& Waters, G. (1999). Verbal working memory and sentence comprehension. Behavioral and Brain Sciences, 22, 77-126.

Carlson, G. N., \& Tanenhaus, M. K. (1988). Thematic roles and language comprehension. In W. Wilkins (Ed.), Thematic relations. New York, NY: Academic Press.

Carrier-Duncan, J. (1985). Linking of thematic roles in derivational word formation. Linguistic Inquiry, 16(1), 1-34.

Cho, M. H. (1982). Language acquisition research of Korean children: strategy model. Seoul: Seoul National University Press.

Chomsky, N. (1986). Knowledge of language: its nature, origin, and use. Westport: Praegar Publishers.

Christensen, K. J., Multhaup, K. S., Nordstrom, S., \& Voss, K. (1991). A cognitive battery for dementia: development and measurement characteristics. Psychological Assessment: A Journal of Consulting and Clinical Psychology, 3(2), 168-174.

Crocker, M. W., \& Brants, T. (2000). Wide-coverage probabilistic sentence processing. Journal of Psycholinguistic Research, 29(6), 647-669.

Dickey, M. W., \& Warren, T. (2015). The influence of event-related knowledge on verb-argument processing in aphasia. Neuropsychologia, 67, 6381.

Dik, S. C. (1997). The theory of functional grammar: the structure of the clause. Berlin: Mouton de Gruyter.

Dragoy, O., Bergelson, M., Iskra, E., Laurinavichyute, A., Mannova, E., Skvortsova, A., \& Statnikov, A. (2016). Comprehension of reversible constructions in semantic aphasia. Aphasiology, 30(1), 1-22.

Edmonds, L. A., Nadeau, S. E., \& Kiran, S. (2009). Effects of verb network strengthening treatment (VNeST) on lexical retrieval of content words in sentences in persons with aphasia. Aphasiology, 23(3), 402-424.

Ferretti, T. R., McRae, K., \& Hatherell, A. (2001). Integrating verbs, situation schemas, and thematic role concepts. Journal of Memory and Language, 44(4), 516-547.
Fillmore, C. (1968). Lexical entries for verbs. Foundations of Language, 4(4), 3-393.

Friederici, A. D. (1982). Syntactic and semantic processes in aphasic deficits: the availability of prepositions. Brain and Language, 15(2), 249-258.

Friederici, A. D., \& Frazier, L. (1992). Thematic analysis in agrammatic comprehension: syntactic structures and task demands. Brain and Language, 42(1), 1-29.

Givón, T. (1983). Topic continuity in discourse: an introduction. In T. Givón (Ed.), Topic continuity in discourse: a quantitative, crosslanguage study (pp. 1-42). New York City, NY: John Benjamins Publishing Company. Grimshaw, J. (1990). Argument structure. Cambridge, MA: MIT Press.

Grodzinsky, Y. (1986). Language deficits and the theory of syntax. Brain and Language, 27(1), 135-159.

Hagiwara, H., \& Caplan, D. (1990). Syntactic comprehension in Japanese aphasics: effects of category and thematic role order. Brain and Language, 38(1), 159-170.

Han, J. (2018). Grammaticalization of Korean case markers: focused on adverbial case markers. The Research Society of Language and Literature, 96, 69-88.

Han, J. H. (2001). Thematic hierarchy and Korean subject and object. The Association for Korean Linguistics, 13(6), 303-321.

Hula, W. D., \& McNeil, M. R. (2008). Models of attention and dual-task performance as explanatory constructs in aphasia. Seminars in Speech and Language, 29(3), 169-187.

Hwang, M. (2003). The production of grammatical morphemes of Korean children language impairments. Speech Sciences, 10(3), 47-64.

Hyun, J. M., Sung, J. E., Jeong, J. H., Kang, H. J., \& Kim, H. J. (2013). Effects of syntactic complexity on a case marker processing task in people with mild cognitive impairment. Communication Sciences \& Disorders, 18(1), $35-46$.

Im, H. P. (2007). Language typological approach to word order and basic word order of Korean. Humanities Research Institute, 22, 53-120.

Jackendoff, R. S. (1972). Semantic interpretation in generative grammar. Cambridge, MA: The MIT Press.

Jeong, K. H., \& Sung, J. E. (2018). Verbs and their thematic role processing abilities for people with aphasia. Communication Sciences \& Disorders, 23(2), 337-346.

Jonkers, R., \& Bastiaanse, R. (1996). The influence of instrumentalitry and transitivity on action naming in broca's and anomic aphasia. Brain and Language, 55(1), 37-39. 
Jonkers, R., \& Bastiaanse, R. (2007). Action naming in anomic speakers: effects of instrumentality and name relation. Brain and Language, 102(3), 262-272.

Kang, Y. (2006). A normative study of the Korean-Mini Mental State Examination (K-MMSE) in the elderly. The Korean Psychological Association, 25(2), 1-12.

Kang, Y. W., Chin, J. H., Na, D. L., Lee, J., \& Park, J. S. (2000). A normative study of the Korean version of Controlled Oral Word Association Test (COWAT) in the elderly. Korean Journal of Clinical Psychology, 19(2), 385392.

Kang, Y., Jahang, S. M., \& Na, D. R. (2012). Seoul Neuropsycological Screening Battery-II (SNSB-II). Seoul: Human Brain Research \& Consulting.

Kang, Y. W., Na, D. L., \& Hahn, S. H. (1997). A validity study on the Korean Mini-Mental State Examination (K-MMSE) in dementia patients. Journal of the Korean Neurological Association, 15(2), 300-308.

Kim, H. H., \& Na, D. L. (2012). Paradise. Korean version-the Western Aphasia Battery-Revised (PK-WAB-R). Seoul: Paradise.

Kim, Y. J., \& Woo, J. H. (2007). The processing of thematic role information in Korean verbs. Korean Journal of Cognitive Science, 18(2), 91-112.

Kittredge, A. K., Dell, G. S., Verkuilen, J., \& Schwartz, M. F. (2008). Where is the effect of frequency in word production? Insights from aphasic picturenaming errors. Cognitive Neuropsychology, 25(4), 463-492.

Knobel, M., Finkbeiner, M., \& Caramazza, A. (2008). The many places of frequency: evidence for a novel locus of the lexical frequency effect in word production. Cognitive Neuropsychology, 25(2), 256-286.

Koenig, J., Mauner, G., \& Bienvenue, B. (2003). Arguments for adjuncts. Cognition, 89(2), 67-103.

Kwag, E. J., Sung, J. E., Kim, Y. H., \& Cheon, H. J. (2014). Effects of verb network strengthening treatment on retrieval of verbs and nouns in persons with aphasia. Communication Sciences \& Disorders, 19(1), 89-98.

Kwon, J. (2009). Korean syntax. Seoul: Minumsa.

Kwon, J. I. (1989). A method of description for the case-markers and their deletion in Korean. Language Research, 25(1), 129-139.

Laiacona, M., Luzzatti, C., Zonca, G., Guarnaschelli, C., \& Capitani, E. (2001). Lexical and semantic factors influencing picture naming in aphasia. Brain and Cognition, 46(1-2), 184-187.

Lee, S. J., Kim, H., Seo, S., \& Kim, M. (2009). Patterns of word class production between picture description and narrative tasks in aphasia. Korean Journal of Communication Disorders, 14(4), 470-483.

Levelt, W. J. M. (1989). Speaking: from intention to articulation. Cambridge,
MA: MIT Press.

Linebarger, M., Schwartz, M., \& Saffran, E. (1983). Sensitivity to grammatical structure in so-called agrammatic aphasics. Cognition, 13(3), 361-92.

MacWhinney, B., Osman-Sagi, J., \& Slobin, D. I. (1991). Sentence comprehension in two clear case-marking languages. Brain and Language, 41(2), 234-249.

Marková, J., \& Cséfalvay, Z. (2010). Morphological-syntactic deficits in the production of Slovak-speaking aphasic patients. Aphasiology, 24(10), 1197-1222.

McRae, K., Hare, M., \& Tanenhaus, M. K. (2005). Meaning through syntax is insufficient to explain comprehension of sentences with reduced relative clauses: comment on McKoon and Ratcliff (2003). Psychological Review, 112(4), 1022-1031.

Miceli, G., Silveri, M. C., Romani, C., \& Caramazza, A., (1989). Variation in the pattern of omissions and substitutions of grammatical morphemes in the spontaneous speech of so-called agrammatic patients. Brain and Language, 36(3), 447-492.

Murray, L. L. (2012). Attention and other cognitive deficits in aphasia: presence and relation to language and communication measures. American Journal of Speech-Language Pathology, 21(2), 51-64.

Murray, L. L., \& Kean, J. (2004). Resource theory and aphasia: time to abandon or time to revise?. Aphasiology, 18, 830-835.

Nam, M. H. (1988). Study on word order in Korean (Master's thesis). Seoul National University, Seoul, Korea.

Nam, K. C., Yim, C. G., Jung, J. B., Kim, D. H., \& Pyun, S. B. (1999). Agrammatism in broca's aphasia: dissociation of sentence production and comprehension. The Korean Journal of Psychology, 18(1), 49-64.

Nickels, L., \& Howard, D. (1994). A frequent occurrence? Factors affecting the production of semantic errors in aphasic naming. Cognitive Neuropsychology, 11(3), 289-320.

Nozari, N., Kittredge, A. K., Dell, G. S., \& Schwartz, M. F. (2010). Naming and repetition in aphasia: steps, routes, and frequency effects. Journal of Memory and Language, 63(4), 541-559.

Park, Y., Goral, M., Verkuilen, J., \& Kempler, D. (2013). Effects of noun-verb conceptual/phonological relatedness on verb production changes in broca’s aphasia. Aphasiology, 27(7), 811-827.

Park, J., \& Choi, Y. (2011). Comprehension of wh-questions in broca's aphasia. Journal of Rehabilitation Research, 15(2), 55-74.

Rayner, K., Carlson, M., \& Frazier, L. (1983). The interaction of syntax and semantics during sentence processing: eye movements in the analysis of 
semantically biased sentences. Journal of Verbal Learning and Verbal Behavior, 22(3), 358-364.

Saffran, E. M., Schwartz, M. F., \& Marin, O. S. (1980). The word order problem in agrammatism: II. Production. Brain and Language, 10(2), 263-280.

Schwartz, M. F., Saffran, E. M., \& Marin, O. S. M. (1980). The word order problem in agrammatism: I. Comprehension. Brain and Language, 10(2), 249-262.

Seo, S. K. (1998). The lexicon frequency of contemporary Korean based on the Yonsei corpus 1-9. Seoul: Institute of Language and Information Studies.

Slobin, D. I. (1973). Cognitive prerequisites for the development of grammar. In C. A. Ferguson, \& D. I. Slobin (Eds.), Studies of child language development (pp. 175-208). New York, NY: Holt, Rinehart, \& Winston.

Slobin, D. I. (1991). Aphasia in Turkish: speech production in broca's and wernicke's patients. Brain and Language, 41(2), 149-164.

Sohn, H. (2001). The Korean language. Cambridge, MA: Cambridge University Press.

Speas, M. J. (1990). Phrase structure in natural languages. Dordrecht: Kluwer Academic Publishers.

Sung, J. E. (2016). The effects of verb argument complexity on verb production in persons with aphasia: evidence from a subject-object-verb language. Journal of Psycholinguistic Research, 45, 287-305.
Sung, J. E. (2017). Age-related decline in case-marker processing and its relation to working memory capacity. Journals of Gerontology: Psychological Sciences, 72(5), 813-820.

Thompson, C. K. (2019). Neurocognitive recovery of sentence processing in aphasia. Journal of Speech, Language, and Hearing Research, 62(11), 39473972.

Van Valin, R. D. (1990). Semantic parameters of split intransitivity. Language, 66(2), 221-260.

Wambaugh, J. L., Doyle, P. J., Martinez, A. L., \& Kalinyak-Fliszar, M. (2002). Effects of two lexical retrieval cueing treatments on action naming in aphasia. Journal of Rehabilitation Research and Development, 39(4), 455466.

Webster, J., Franklin, S., \& Howard, D. (2007). An analysis of thematic and phrasal structure in people with aphasia: What more can we learn from the story of Cinderella?. Journal of Neurolinguistics, 20(5), 363-394.

Willits, J., D’Mello, S., Duran, N., \& Olney, A. (2007). Distributional statistics and thematic role relationships. In D. S. McNamara, \& J. G. Trafton (Eds.), Proceedings of the 29th annual conference of the Cognitive Science Society (pp. 707-712). Austin, TX.: Cognitive Science Society.

Yi, H. (2019). On the classification of semantic roles. Korean Language and Culture, 26, 95-120. 
Appendix 1. 선정된 자극 목록

\begin{tabular}{|c|c|c|c|c|c|}
\hline \multicolumn{3}{|c|}{ ‘도구, 대상' 명사 및 서술어 } & \multicolumn{3}{|c|}{ '장소, 대상' 명사 및 서술어 } \\
\hline 도구 & 대상 & 서술어 & 장소 & 대상 & 서술어 \\
\hline 열쇠 & 문 & 열다 & 엉덩이 & 주사 & 놓다 \\
\hline 연필 & 이름 & 쓰다 & 상자 & 물건 & 넣다 \\
\hline 낫 & 곡식 & 베다 & 봉투 & 쓰레기 & 담다 \\
\hline 바늘 & 양말 & 꿰매다 & 선반 & 액자 & 놓다 \\
\hline 숟가락 & 밥 & 먹다 & 쟁반 & 과일 & 담다 \\
\hline 젓가락 & 나물 & 집다 & 가방 & 책 & 넣다 \\
\hline 가위 & 종이 & 자르다 & 나무 & 둥지 & 틀다 \\
\hline 망치 & 못 & 박다 & 손목 & 시계 & 차다 \\
\hline 빗자루 & 낙엽 & 쓸다 & 화분 & 씨 & 심다 \\
\hline 칼 & 껍질 & 깎다 & 바구니 & 사과 & 담다 \\
\hline 비누 & 손 & 씻다 & 컵 & 우유 & 따르다 \\
\hline 카메라 & 사진 & 찍다 & 칠판 & 자석 & 붙이다 \\
\hline 걸레 & 얼룩 & 지우다 & 접시 & 반찬 & 담다 \\
\hline 삽 & 흙 & 푸다 & 바닥 & 돗자리 & 펴다 \\
\hline 돌멩이 & 탑 & 쌓다 & 공책 & 일기 & 쓰다 \\
\hline 톱 & 나무토막 & 자르다 & 트렁크 & 짐 & 싣다 \\
\hline 풀 & 우표 & 붙이다 & 손가락 & 반창고 & 붙이다 \\
\hline 붓 & 그림 & 그리다 & 국 & 간장 & 넣다 \\
\hline 자 & 길이 & 재다 & 꽃 & 물 & 주다 \\
\hline 끈 & 머리카락 & 묶다 & 수첩 & 글 & 쓰다 \\
\hline
\end{tabular}

Appendix 2. 의미역 명사 유형별 조사 오류 유형 및 반응 예시

\begin{tabular}{|c|c|c|c|}
\hline $\begin{array}{l}\text { 의미역 명사 유형 별 } \\
\text { 조사 유형 }\end{array}$ & 오류 유형 & 오류 반응 & 오류 예시 \\
\hline \multirow[t]{9}{*}{ 도구격 조사(도구) } & "망치로 못을 박다" & & \\
\hline & 대치 & 주격 & 로 $\rightarrow$ 가 \\
\hline & & 목적격 & 로 $\rightarrow$ 를 \\
\hline & & 관형격 & 로 $\rightarrow$ 의 \\
\hline & & 처소격 & 로 $\rightarrow$ 에 \\
\hline & & 동반격 & 로 $\rightarrow$ 이랑/와 \\
\hline & & 여격 & 로 $\rightarrow$ 에게/한테 \\
\hline & & 보조사 & 로 $\rightarrow$ 는/도 \\
\hline & 생략 & & 로 $\rightarrow x$ \\
\hline \multirow[t]{9}{*}{ 처소격 조사(장소) } & "컵에 우유를 따르다" & & \\
\hline & 대치 & 주격 & 에 $\rightarrow$ 이 \\
\hline & & 목적격 & 에 $\rightarrow$ 을 \\
\hline & & 관형격 & 에 $\rightarrow$ 의 \\
\hline & & 도구격 & 에 $\rightarrow$ 으로 \\
\hline & & 동반격 & 에 $\rightarrow$ 이랑/와 \\
\hline & & 여격 & 에 $\rightarrow$ 에게/한테 \\
\hline & & 보조사 & 에 $\rightarrow$ 은/도 \\
\hline & 생략 & & 에 $\rightarrow x$ \\
\hline \multirow[t]{9}{*}{ 목적격 조사(대상) } & "과일을 쟁반에 담다" & & \\
\hline & 대치 & 주격 & 을 $\rightarrow$ 이 \\
\hline & & 관형격 & 을 $\rightarrow$ 의 \\
\hline & & 도구격 & 을 $\rightarrow$ 로 \\
\hline & & 처소격 & 을 $\rightarrow$ 에 \\
\hline & & 여격 & 을 $\rightarrow$ 에게/한테 \\
\hline & & 동반격 & 을 $\rightarrow$ 이랑/과 \\
\hline & & 보조사 & 을 $\rightarrow$ 은/도 \\
\hline & 생략 & & 을 $\rightarrow x$ \\
\hline
\end{tabular}




\section{국문초록}

\section{의미역 명사 유형에 따른 실어증 환자의 조사 산출 능력}

박지민 · 성지은

이화여자대학교 대학원 언어병리학과

배경 및 목적: 본 연구는 의미역 명사 유형에 따른 실어증 환자의 조사 산출 능력과 실어증 환자의 조사 오류 유형 및 반응을 분석하고 자 한다. 또한 실어증 중증도를 가장 잘 예측하는 의미역 명사 유형이 무엇인지 알아보고자 한다. 방법: 실어증 환자 18 명, 정상 성인 20 명이 본 연구에 참여하였다. 대상자는 글자로 제시된 2 개의 의미역 명사와 1 개의 서술어를 보고 적절한 조사를 산출하였다. 결과: 첫째, 실어증 환자는 정상 성인보다 유의하게 낮은 정반응률을 보였으며, 장소 및 대상 의미역 명사에 비해 도구에서 특히 낮았다. 둘째, 실어 증 환자의 오류 유형은 주로 대치였으며, 굴절어의 오류 특징과 일치하였다. 도구와장소 의미역 명사에서의 조사는 목적격으로, 대상에 서는 처소격으로 가장 많이 대치되었다. 셋째, 장소 의미역 명사가 실어증 중증도를 $48.2 \%$ 로 예측하는 것으로 나타났다. 논의 및 결론: 실어증 환자는 통사적 및 의미적으로 논항 관계를 파악하는데 어려움을 보여 정상 성인에 비해 유의하게 낮은 결과를 보였다. 또한 빈 도 효과에 따른 어휘 인출 능력과 실어증 환자들의 보존된 공간 인식 능력으로 인해 장소 의미역이 실어증 중증도를 예측하는 것으로 나타났다. 실시가 간편하고 실어증 중증도를 변별할 수 있다는 점에서 임상적 시사점을 가진다.

핵심어: 의미역, 조사, 동사, 실어증

본 연구는 대한민국 교육부와 한국연구재단의 지원을 받아 수행된 연구임(No. NRF-2019R1A2C1089280).

\section{참고문헌}

강연욱(2006). K-MMSE (Korean-mini mental state examination)의 노인 규준 연구. 한국심리학회지: 일반, 25(2), 1-12. 강연욱, 나덕렬, 한승혜(1997). 치매환자들을 대상으로 한 K-MMSE의 타당도연구. 대한신경과학회지, 15(2), 300-308.

강연욱, 장승민, 나덕렬(2012). 서울신경심리검사 2판. 서울: 휴브알엔씨.

강연욱, 진주희, 나덕렬, 이정희, 박재설(2000). 통제 단어 연상 검사의 노인 규준 연구. 한국심리학회, 19(2), 385-392.

곽은정, 성지은, 김연희, 전희정(2014). 동사의미역강화중재가 실어증 환자의 동사 및 명사 이름대기에 미치는 효과. Communication Sciences \& Disorders, 19(1), 89-98.

권재일(1989). 조사의 성격과 그 생략 현상에 대한 기술 방법. 어학연구, 25(1), 129-139.

김영진, 우정희(2007). 한국어 동사의 의미역정보 처리과정. 인지과학, 18(2), 91-112.

김향희, 나덕렬(2012). 파라다이스 한국판 웨스턴 실어증 검사-개정판. 서울: 파라다이스.

남미혜(1988). 국어 어순 연구: 어순 재배치 현상을 중심으로. 서울대학교 대학원 석사학위논문.

남기춘, 임창국, 정재범, 김동휘, 편성범(1999). 브로카 실어증의 실문법증: 격조사산출과 이해의 해리. 한국심리학회지, 18(1), 49-64.

박정은, 최예린(2011). 브로카 실어증 환자의 의문문 이해. 한국장애인재활협회, 15(2), 55-74.

서상규(1998). 연세말뭉치 1-9를 대상으로 한 현대한국어의 어휘빈도. 서울: 연세대학교 언어정보개발연구원.

이승진, 김향희, 서상규, 김미경(2009). 유창성 및 과제에 따른 실어증 환자의 품사산출의 양상 비교. 언어청각장애연구, 14(4), 470-483.

이홍식(2019). 의미역의 분류에 대하여. 한국어와문화, 26, 95-120.

임홍빈(2007). 어순에 관한 언어 유형적 접근과 한국어의 기본 어순. 서강대학교인문과학연구소, 22, 53-120.

정귀현, 성지은(2018). 의미역 유형에 따른 실어증 환자의 동사 및 의미역 처리 능력과 중증도 간의 관계. Communication Sciences \& Disorders,

23(2), 337-346.

조명한(1982). 한국아동의 언어 획득 연구: 책략모형. 서울: 서울대학교 출판사. 
한정한(2001). 의미역 계층이론과 국어의 주격, 대격. 한국어학, 13(6), 303-321.

한주희(2018). 한국어 어휘격, 부사격 조사의 문법화양상. 어문연구, 96, 69-88.

현정민, 성지은, 정지향, 강희진, 김희진(2013). 경도인지장애 환자의 통사적 복잡성에 따른 격조사처리능력. Communication Sciences \& Disorders,

$18(1), 35-46$.

황민아(2003). 언어발달장애 아동의 문법형태소 산출. 음성과학, 10(3), 47-64.

\section{ORCID}

박지민(제1저자, 대학원생 https://orcid.org/0000-0002-3367-893X); 성지은(교신저자, 교수 https://orcid.org/0000-0002-1734-0058) 